\title{
SEASIONAL AND ALTITUDINAL DIVERSITY OF BUTTERFLIES IN EASTERN SIWALIK OF NEPAL
}

\author{
D. R. Bhusal and B. Khanal
}

\begin{abstract}
Study on butterfly diversity at Churiya range of eastern Nepal in winter and spring was conducted during December 1999 to May 2000. Collection sites ranged from $<250$ to $>1150$ $\mathrm{m}$ in altitude where a total of 40 species of butterflies belonging to 28 genera and eight families were recorded. Both of seasonal and altitudinal effects on the abundance of butterflies were noticed in the area. Species richness increased with upcoming warmer spring days at low and midland areas while decreased in higher elevations.
\end{abstract}

Key words: Altitudinal, diversity, seasonal, abundance, species richness.

\section{Introduction}

A total of 650 species of butterflies are reported in Nepal which is equal to about $4.3 \%$ of the globally known species (Prajapati et.al. 2000). Distribution patterns of Nepalese butterflies are varied with respect to physiographic zones which include $51 \%$ in Terai and Siwalik zone, $88 \%$ in middle zone and $13 \%$ in the highland zone of the country. About $18 \%$ species of the mid hill zones are considered threatened. (BPN, 1996). The area of Siwalik includes various tropical and sub-tropical forest types and receive higher rate of precipitation than western Nepal. So this variation in forest types has wider range of habitats to offer for diverse butterfly species (Smith 1994).

\section{Study Area}

The Siwalik, also known as Churiya comprises the southernmost mountain-belt of the Hindu Kush Himalaya. Geologically, the Churiya is very rugged and unstable (Hagen, 1998) with exceedingly flashy river systems (Jhingra, 1981). This study area is a part of eastern Siwalik (200 40' - 270 53' N, 870 08' - 880 11') which extends $103 \mathrm{~km}$ from Koshi to Mechi Rivers covering the area of 77,924 ha. The width of this part varies from $50 \mathrm{~km}$ to nearly $20 \mathrm{~km}$ (Yonzen et.al, 2000). Rapidly increasing population of human is impacting forest resources which eventual is causing the loss of many valuable macro-habitats of rare butterfly species.

\section{Materials and Methods}

Butterfly specimens were collected in different areas and altitudes. of eastern Siwalik by random sampling method (Yonzon et. al 2000) Sampling plots for data collection were ascertained using geographical grids on 1992 map using Random Table of Rohlf and Sokol (1969). In the field the grids were located with the help of Global Positioning System. Collection of specimens was carried out in February to May emphasizing winter and spring seasons. The specimens of butterflies were collected at different altitudinal ranges at $250 \mathrm{~m}$ to $1150 \mathrm{~m}$ which included various habitat types like cultivated land, river bank, forest edges, open and bushy areas etc. 
All the collected specimens were identified with the help of various relevant literatures like Wynter and Blyth (1957), Shirozu (1960), Smith (1994), (Khanal and Smith 1997). These were reconfirmed at Natural History Museum Swayambhu in Katmandu.

\section{Result}

The record of 40 species, 28 genera and 8 families of butterflies have been made in this study which is about $6.29 \%$ of the total known species of the nation. The family Nymphalidae displayed highest species number which is equivalent to $37.5 \%$ of the total report of this study, families like Hesperiidae and Nemeobiidae represented least number of species which equals to $2.5 \%$ each.

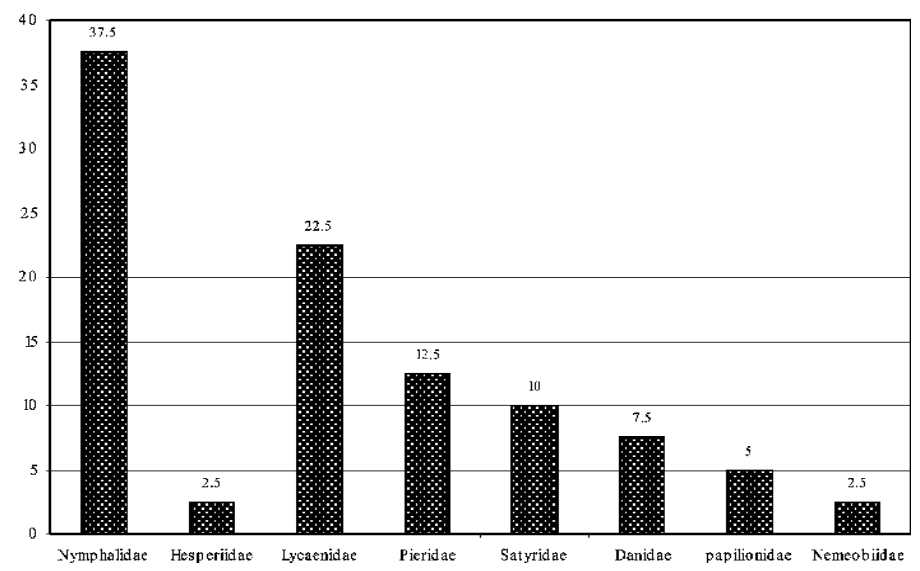

Fig 1. Composition of Recorded Species by Families

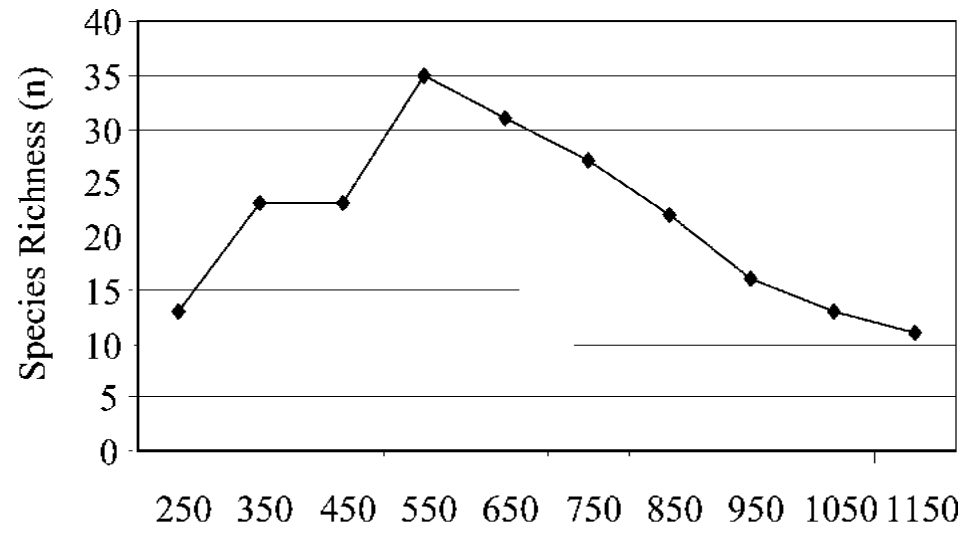

Altitude

Graph 1. Relation between Altitude and Species richness 
A list of butterflies occurring in two different seasons.

\begin{tabular}{|c|c|c|c|c|c|}
\hline \multirow[t]{2}{*}{ Family } & \multirow[t]{2}{*}{ S.N. } & \multirow[t]{2}{*}{ Genus } & \multirow[t]{2}{*}{ Species } & \multicolumn{2}{|c|}{$\begin{array}{l}\text { Seasonal } \\
\text { Variation }\end{array}$} \\
\hline & & & & Winter & Spring \\
\hline \multirow{2}{*}{ Papilionidae } & 1 & Pachiliopta & aristolocite & - & + \\
\hline & 2 & Papilio & demoleus & - & + \\
\hline \multirow{5}{*}{ Pieridae } & 1 & Delias & descombesi & + & - \\
\hline & 2 & Delias & hyparete & - & + \\
\hline & 3 & Eurema & hecabe & + & + \\
\hline & 4 & Gonepteryx & rhamni & + & + \\
\hline & 5 & Pieros & brassocae & + & + \\
\hline \multirow{8}{*}{ Lycaenidae } & 1 & Aprophala & pesudocentaurus & - & + \\
\hline & 2 & Celastrina & puspa & + & + \\
\hline & 3 & Heliophorous & epicle & - & + \\
\hline & 4 & Jamides & alecto & + & + \\
\hline & 5 & Lampides & boeticus & + & - \\
\hline & 6 & Zizeeria & maha & + & - \\
\hline & 7 & Zizeeria & otis & - & + \\
\hline & 8 & Celastrina & dilectus & + & - \\
\hline Nemeobiidae & 1 & Abisara & fylla & - & + \\
\hline \multirow[b]{7}{*}{ Nymphalidae } & 1 & Athyma & jina & - & + \\
\hline & 2 & Athyma & selenophora & + & - \\
\hline & 3 & Precis & almana & + & + \\
\hline & 4 & Neptis & hylas & + & - \\
\hline & 5 & Precis & atlites & - & + \\
\hline & 6 & Precis & iphita & - & - \\
\hline & 7 & Junonia & orithya & - & + \\
\hline
\end{tabular}




\begin{tabular}{|c|c|l|l|c|c|}
\hline \multirow{5}{*}{} & 8 & Neptis & cortica & - & + \\
\cline { 2 - 6 } & 9 & Tanaecia & lepidae & + & - \\
\cline { 2 - 6 } & 10 & Symbrentha & lilea & - & + \\
\cline { 2 - 6 } & 11 & Melanitis & leda & + & + \\
\cline { 2 - 6 } & 12 & Athyma & perius & - & + \\
\cline { 2 - 6 } & 13 & Neptis & hordonia & + & - \\
\cline { 2 - 6 } & 14 & Athyma & opalina & + & - \\
\cline { 2 - 6 } & 15 & Precis & hierta & - & + \\
\hline \multirow{5}{*}{ Danaidae } & 2 & Danaus & aglea & - & + \\
\cline { 2 - 6 } & 3 & Euploena & core & - & + \\
\hline \multirow{5}{*}{ Hesperidae } & 1 & Tagiages & litigiosa & & + \\
\hline
\end{tabular}

(-) Sign indicates absence and (+) sign indicate presence of specimens.

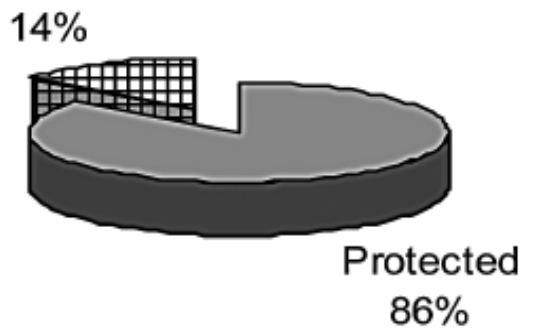

$\square$ Protected $\boxplus$ Open

Figure 2. Seasonal Composition of Recorded Species in Percentage 


\section{Discussion}

Being located in the tropical and sub-tropical zone, the eastern Siwalik has a good diversity of butterfly due to its diversified vegetations, preferable habitat types and different climatic factors.

The altitudinal diversity of butterfly in the study area showed gradual species increase up to $550 \mathrm{~m}$ of elevation. The species richness was observed minimum at the highest altitude of $1150 \mathrm{~m}$. Optimum altitudinal range for rich diversity was found at 350 to $850 \mathrm{~m}$. The correlation coefficient between the altitude and species richness was found to be of negative significance.

In this study, members of Nymphalidae reached to the maximum diversity (37.5\%) and least representation was made from Hesperidae and Nemeobiidae (2.5\%) each. At this altitude, a shrub called Leea $s p$. was observed frequently which is the suitable food plant for many butterfly species (Haribal, 1992). Some species like Pieris brassicae, Precis iphita, Junonia orithya and Melanitis leda were observed in all the altitudes whereas Elymnias malelas, E. hyperministra, Heliophorous epicle and Abisara fylla were noticed at lower elevations only. Gonepteryx rhamni, Athyma jina, Delias descombesi and Tagiades litigiosa were reported at higher areas. Same species were observed by Khanal and Smith (1997) at 1500 in the southern part of Kathmandu city.

Analyzing the seasonal diversity data of butterflies of this area, $30 \%$ were recorded in winter, $52 \%$ in spring and $18 \%$ in either season. This revealed the occurrence of rich diversity in spring than winter. It also explains that there is a significant correlation between species diversity and spring season indicating the abundances of diverse species was positively affected by approaching warmer days, high relative humidity and more rainfall. These factors help to flourish diverse vegetations, which are vital food sources for many butterfly species. It was observed that some species like Gonepteryx rhamni, Pieris brassicae, Celastrina puspa, Jamides alecto, Eurema hecabe, Melanitis leda, Elymnias hyperminispra, Lethe confusa etc. exist both in winter and spring seasons. Overall results coincide to Smith's work (1997) of eastern Nepal.

The report of Kunte (1997) also revealed similar result showing rapid increasing of Nymphalidae at the time when plants were in suitable phenophase for the growth of the caterpillars. Guiterrez and Memendez (1995) suggested that the abundance of butterflies is not affected by altitudes but it is more related to the availability of food plants. A similar seasonal variation in species abundance was observed by Prajapati et.al. (2000) in Daman of Makawanpur district of central Nepal.

\section{Acknowledgment}

We thank to Churia ecological project /Resources Himalaya, Nepal. It provided research grant and technical assistance to the first author. 


\section{References}

BPN, (1996). Biodiversity Profile of Nepal with special reference to protected area. Dept. of National Park and Wildlife Conservation HMG/Nepal.

Gutierrez, D. and R. Mendez, (1995). Phenology of butterflies in a mountain area in northern Iberian Peninsual. Ecography, 18:209-2196.

Hagen, T. 1998. Nepal. Himal Books, Lalitpur.

Haribal, M. (1992). The Butterflies of Sikkim Himalaya Nature conservation Foundation, Gangtok.

Jhingra, A.G. (1981). Geology of Himalaya. In: The Himalaya (Ed. J.S. Lall):77-98. Oxford University Press, Oxford.

Khanal, B. and Smith, C. (1997). Butterflies of Kathmandu Valley. Craftsman Press, Bangkok, Thailand.

Kunte, K.J. (1997). Seasonal patterns in butterfly abundance and species diversity in far tropical habitats in northern Western Ghats J. Biosci (Banglore), 22: 593-603.

Prajapati, B.; Shrestha, U. and Tamrakar A.S. (2000). Diversity of Butterfly in Daman Area of Makawanpur District, Central Nepal. Nepal Journal of Science and Technology, 2:71-76.

Rohlf, F. J. and Sokol, J.L. (1969). Statistical Table. W .H.Freeman and Company, Sanfrancisco, California.

Smith, C. (1994). Butterflies of Nepal, Craftsman Press, Bangkok.

Wadi, S.R. And Baldev, P. (1968). Some new records of Butterflies from Nepal, Short Notes: Indian Journal, 30(1):92-93.

Wynter-Blyth, M.A. (1957). Butterflies of India regions. The Bombay Natural History Society, Delhi.

Yonzon, P.; Bhuju, D. and Baidya, B. (2000). Landuse pattern and its change in the Churiya, and D. Bhuju, a report submitted to nature Conservation Society, Japan:1-23. Resources Himalaya, Kathmandu.

\section{Author's Address}

Daya Ram Bhusal and Bhaiya Khanal

Central Department of Zoology, Tribhuvan

University, Kathmandu, Nepal.

Natural Hitory Museum, Swayambhu, Kathmandu, Nepal 